\title{
Spread of endemic disease and global change in an educational project: proposition of relationships developed in a twin partnership
}

\author{
Michela Viale ${ }^{\star}$, Elena Ferrero
}

Università di Torino, Dipartimento di Scienze della Terra, Torino, Italy

\author{
Article history \\ Received December 21, 2011; accepted February 7, 2012. \\ Subject classification: \\ Twin partnership, Dengue fever, Education to sustainability, Global change, Cape Verde.
}

\begin{abstract}
The sudden event of the spread of dengue fever (or break-bone fever) that appeared for the first time in Cape Verde in 2009 revealed that inappropriate management of waste can be considered a major cause of the spread of this disease. Dengue fever is a tropical infectious disease that is caused by the dengue virus. Its vector, the mosquito Aedes aegypti, found an optimal environment for its life cycle in the context of Cape Verde, with the persistence of water in abandoned waste objects. The connection between the topics of Earth sciences and the spread of this disease is not obvious, but it was explored and illustrated in a school partnership. Activities with pupils and students provided an opportunity to investigate how some global phenomena, like climate change (with an increase in local rainfall and higher temperatures), are related to local events, such as the spread of dengue fever. Preventive strategies are conditioned by the geomorphology of the territory and by the complex relationships that connect the geosphere and the biosphere. For this reason, it is important to be aware of the risk of breaking these delicate balances, and hence activating unexpected consequences. The roles played by both partners linked knowledge about the natural dynamics of our planet with the development of appropriate behavior, thus contributing to the formation of responsible citizenship, to preserve and protect the environment. The partnership encouraged students to develop sustainable management strategies against dengue fever, and consequently against waste, actively involving them at school, at home, and in their community. In this study, we present a case study of the role of a school partnership in a complex problem, such as the spread of dengue fever and environmental pollution.
\end{abstract}

\section{Premise}

A twinning project between schools of the Piedmont Region (north-western Italy) and the Republic of Cape Verde explored in its first stage the geomorphological aspects of the territory. In the next stage, it developed an investigation of the pupils' and students' conceptions about the geological risks in the area. Further educational research of the students' perception of waste and its dangers highlighted the connection between the physical charac- teristics of the territory, the different ways of managing waste, and the correlation with socio-economic problems [Calvo et al. 2009], which revealed many similarities between the two partners.

The school twinning and cooperation project was based on some general principles according to which it was necessary to share from the beginning of planning a deep and not only formal agreement, with reference to the objectives, the procedures, and the methods to follow. The essential basic condition was to develop a common course on selected and shared topics in the planning stage, to make sure that the issues were significant for both of the partners, were easily accessible for school and family, and if possible, were an integral part of the daily reality of each.

The level of detail could have been calibrated according to age, but the topics were the same for all pairs of the twinning partners.

\section{Introduction}

The research included a curriculum for environmental education in a process of education for sustainability and for the training of tomorrow's citizens, according to the following aims:

- to actively participate in the education and training of responsible citizens;

- to highlight the importance of Earth Sciences for the management and protection of the environment;

- to propose a didactic trail, for both the young and adults.

The objectives were aimed at achieving disciplinary knowledge (related to the curriculum or not), skills, and abilities (linguistic, analytical, and logical thinking):

- to detect and exploit the correlation between the emotional and cognitive study of twinning in various disciplines (history, geography, art, science and computer science);

- to propose a course of education for sustainability at different levels: cognitive, emotional, between teachers, 
between students, and between teachers and students, of the twin countries;

- to investigate how the students of the two partner countries perceive waste, and to compare the results in their socio-economic context;

- to produce a didactic tool to highlight the correlation between local and global aspects ('bad' waste management, climate change, and the spread of dengue fever);

- to produce didactic tools to be presented to the student and teacher partners to maintain the path of twinning and to directly involve the participants in the exchange of reports and discussions.

Several years of international cooperation between Italy and Cape Verde Republic in the field of environmental education have led to an enriching interchange among the teachers and students, and to interesting results about primitive conceptions and misconceptions of the topics explored [Ferrero et al. 2006, 2007]. The main results relating to some of the students' skills were:

a) to improve the individual awareness of local risks, connected to the geological and topographic nature of the territory;

b) to allow the students to discover and experience the information and processes directly in the field;

c) to stimulate interest in the connection between human actions and natural processes;

d) to facilitate the understanding of complex concepts that require a high level of abstract thought;

e) to discuss the results inside the classroom, and to exchange and compare the didactic products with the partners of the other country.

The experience continued over 7 years and involved hundreds of students (aged 6-15 years) who were residents in small settlements or in the most important centers. Some classes had continued for only a few years, although the results of the previous steps of the partnership were always presented to new partners, through synthesis of the products made by the students involved in the project.

The protagonists were ideally matched in pairs, to establish a relationship of personal friendship right from the beginning. Although the Cape Verde classes were more numerous than the Italian ones, this was not a problem. At the beginning, they observed the elements of the landscape near the school, and gradually enlarged the field of investigation, both in space and time [Ferrero et al. 2009a].

The students noted, either directly or with the help of the older members of the family, that the elements of the landscape are not persistent, as seems at the first sight, but that they change over time and are sometimes subject to sudden and catastrophic changes (floods, earthquakes, volcanoes). Later, their attention was driven by the effects of the human presence, and in particular on the pervasive presence of waste, and its origin and destiny, regularly comparing phenomena and processes recognized in both of the countries [Ferrero et al. 2009b].

\section{Materials and methods}

In the case study described in this report, both the Italian students (about 120, from 2 primary school and 4 secondary school classes) and the Cape Verde students (about 200, from 2 primary school and 4 secondary school classes) were asked to work on two worksheets that were structured in the same way, to highlight their preconceptions about the complex and varied topic of waste. They subsequently followed a course of study, which was often different in the different classes and which produced many reports. The worksheets were analyzed with methods using a quasi-statistical approach and the template approach [Viale 2011]. The method suggested to the participating teachers was based on a research model called 'Action Research', in which the teachers become the main players in the practice of education and teaching. The method has been described [Ebbutt 1985, Cattadori et al. 2011] as a systematic study of attempts to improve educational practice by groups of participants, by means of their own practical actions, and by means of their own reflection upon the effects of these actions.

The case study described here was connected with recent episodes of epidemic dengue fever (autumn, 2009 and 2010) that had not been previously present in the Cape Verde islands, and which generated many victims and great concern. At the same time, this stimulated a great venture of information and actions directed to prevent the diffusion of the vector, the mosquito Aedes aegypti. The children in Cape Verde were involved both in fighting the disease and in its prevention, undertaking a role of control in the family and in the neighborhood of the school. Instead, the Italian children were very impressed by the event and were interested in being more informed.

This was a significant case involving a partnership, where the students became aware of complex problems of global relevance that they could share.

\section{The dengue fever outbreak}

Dengue fever and dengue hemorrhagic fever are a serious problem for public health. The primary vector for this disease is a mosquito that is prevalent throughout the tropics, and particularly in urban areas, where the inhabitants are very susceptible to infection. The process of urbanization, which has left many people without water, sewerage and waste recovery systems, has created new sites where the vector can settle, thus speeding up the spread of infection. The virus is transmitted by the bite of various types of mosquitoes, which are active during the day; the principal vector is Aedes aegypti. This virus circulates in the blood of the infected people, and the mosqui- 
If we bite a man who has the Dengue virus in his body, not only the blood but also the virus enters into us...

So, if we then bite another man, we inject this virus into him! He will become ill...

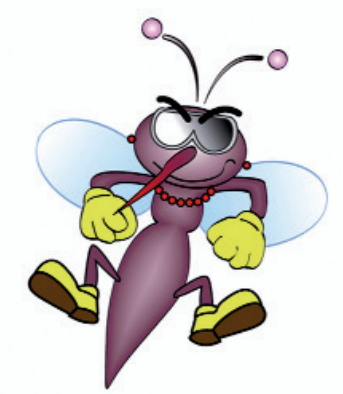

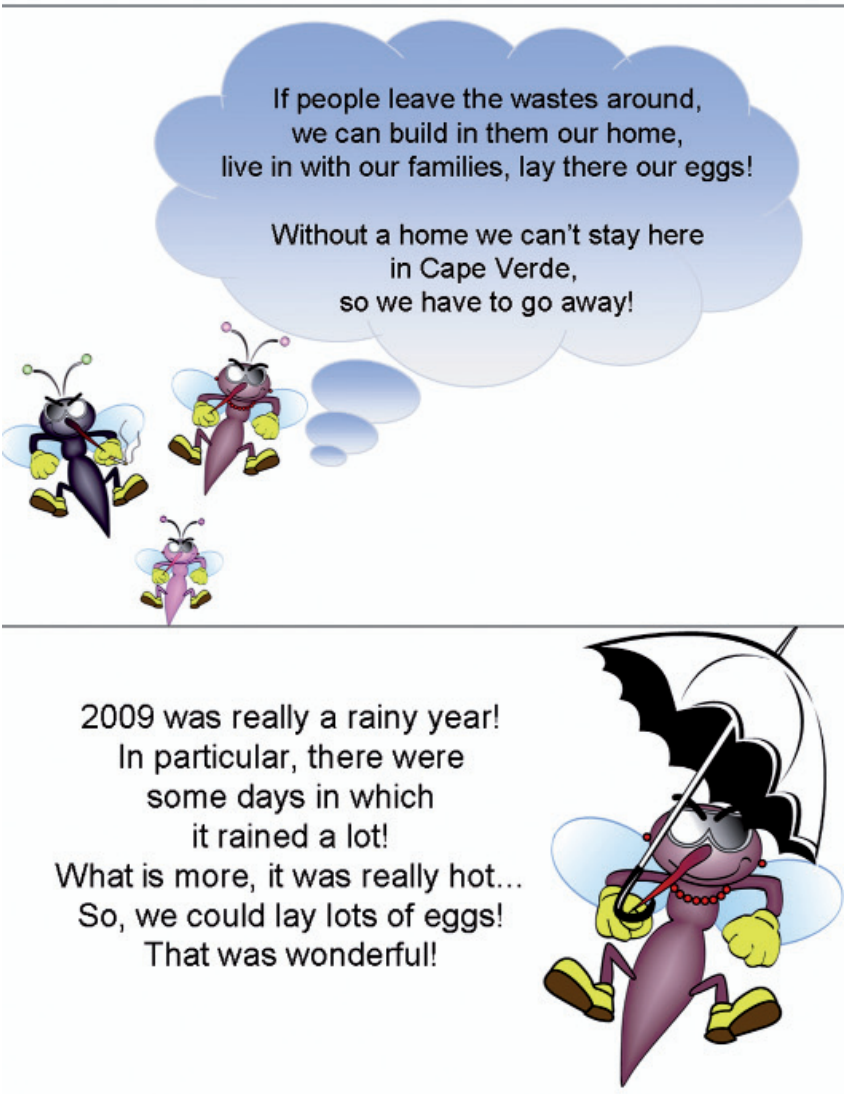

Figure 1. The mosquito Aedes aegypti, the vector of the dengue fever virus. Illustration of the mosquito life cycle, and the environmental conditions favorable to its development and its diffusion.

toes that feed on infected blood remain infected throughout their life. Man acts as an amplifier host for the infection. The female mosquitoes can also transmit the

infection to subsequent generations (http:/ / www.cesmet. $\mathrm{com} /$ planisfero.4/schede/malattie/Dengue.htm).

For the first time, in 2009, dengue fever appeared in Cape Verde, with the most severe outbreak ever recorded in Africa. The number of cases grew at a phenomenal rate from the early days of November 2009, with a peak of 1,000 new cases every day. Indeed, the intense rainfall associated with high temperatures in 2009 provided the mosquito species Aedes aegypti with an excellent habitat to complete its life cycle.

Following the spread of the outbreak, the government distributed informative material on prevention of dengue fever, both direct (use of mosquito nets, repellents) and indirect methods to stop the reproduction cycle of the mosquito. In particular, people were involved in the work of 'cleansing', as the elimination of the waste scattered in the streets and the stagnant water where the mosquitoes lay their eggs. Beyond the innumerable hardships, the spread of dengue fever thus had a favorable outcome for the citizens of Cape Verde, who were active in the fight against garbage and stagnant water in urban and rural areas, thus counteracting the outbreak of the disease [Fidalgo de Barros 2009].

At the same time, the research team produced some original educational material for both the Italian and Cape Verde schools, which included in particular a cartoon-style presentation of the disease, its vector, and its symptoms (Figure 1). For a more engaging and challenging proposal, the vectors directly involved in the disease were chosen and individuated: Rino, Rina and Ritinha (a family of Cape Verde mosquitoes) and Ziro (an Italian mosquito). They were presented to the pupils according to the model the students used to introduce themselves to the twinning partners [Viale 2011].

After viewing the presentation, with the commentary supplied by their teachers, the children produced reports on dengue fever. Some of these were limited to the contents of the 'lesson', while others proposed their own solutions to decrease the incidence of the disease. The expedient of using humanized mosquitoes as narrators impressed the students a lot, and helped them to analyze the problem of dengue fever from a different point of view. They went beyond the symptoms, and they sought to investigate the causes of the diffusion, and to try to propose their solutions.

Drawings showed that the mosquitoes were not perceived as terrible enemies, nor the sole responsible entity for the discomforts of the disease. Contrary-wise, the mosquitoes become dangerous in certain environmental contexts; namely, where there are favorable conditions for their reproduction.

All of the Italian teachers found the effectiveness of communication through drawings; indeed, the drawings revealed the great helpfulness of the misconceptions and 


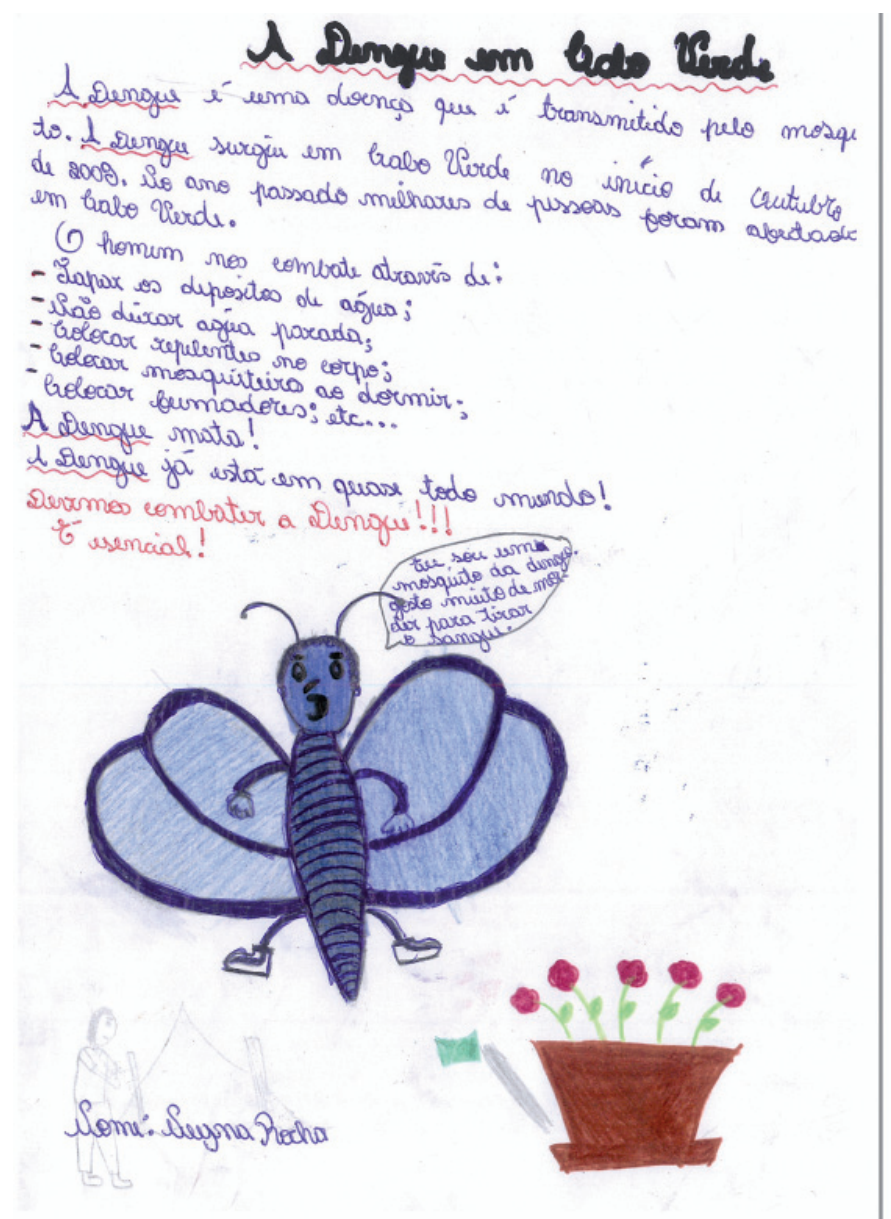

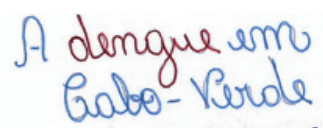

- Ib homerve eombatern nos limpanglo os arrederes das eas 00 , edocand os baldes

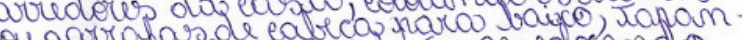

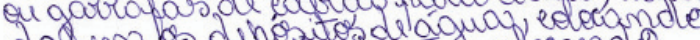

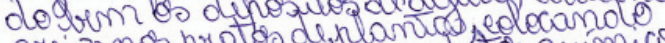
areipo mos voratos de planco stos quémicos

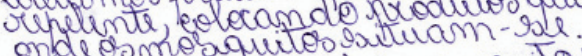

- Adenaur é uma dobncaomuito perigosas, - Adengue éumas doln ca muluéádicarmas a mais brar é as derzeyedengu.

visiternatros tiphos desdengu.

- Sodemos encentrar as larroaradas ato

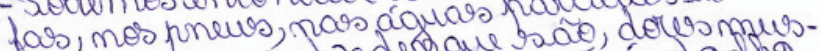

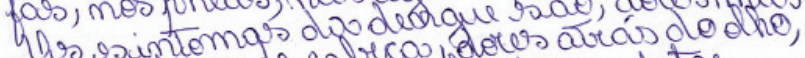

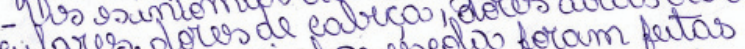
eilares, dores de hoo esseles foram feetas campiarnas de lim puza, pad
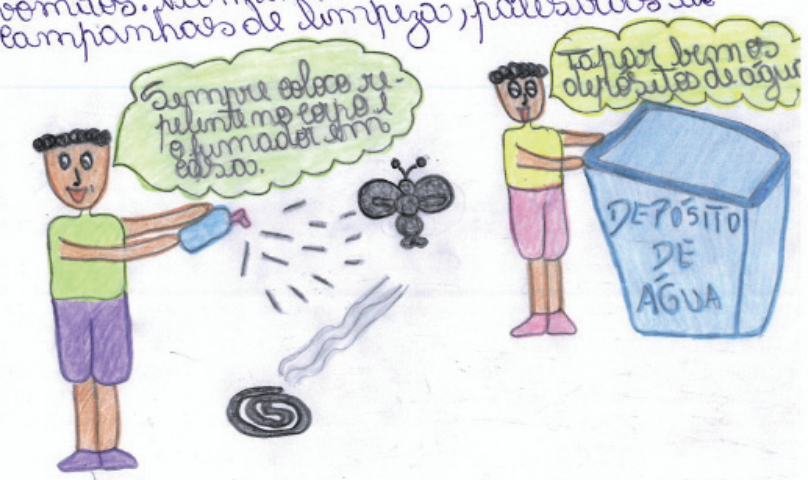

\section{Sosworlatina Ramos D'Aswiar}

Figure 2. Reports of students of primary school in Praia to explain to their Italian partners the best practices to prevent the diffusion of the epidemic spread of the disease. In these drawings, the two students suggest collection of the waste, cleaning of the roads, avoiding leaving water in containers like bottles or cans, not leaving water in plant vases, covering water tanks, avoiding leaving waste around, using repellents, and using mosquito nets during the night.

contradictions in the students' cognitive processes [Hayes et al. 1994, Minuti and Vescovi 1998]. The older students preferred not to use drawings, and very often they opted for the development of multimedia presentations. However, with the help of the teachers, they were able to capture the emotional and affective components in the drawings of their partners and the added value that drawings brought to the cognitive component of communication and knowledge acquisition.

The Italian pupils were particularly involved in the topic, and they expressed interest in deepening these issue. They realized that malaria is still present in Italy, although it is no longer an endemic disease in Italy. They found that the presence of the so-called 'tiger mosquito', which had also been in Piedmont for some years, was concurrent with an increase in the average temperature, and that as another species of tropical mosquito, it can potentially carry new diseases, including dengue fever.

\section{Discussion}

Communications with the partners in Cape Verde, as in other countries in the Sahel, were never easy, because of the distance, the travel and expedition costs, and the lin- guistic and cultural differences. This has always been a critical problem, previously for the choice of the topics to develop, and more recently for the evaluation of the products obtained. Nevertheless, both twin partners were involved in this process of reflection, with the support of didactic tools that were valuable aids. The Cape Verde students presented their preventive strategies, according to the instructions given by the Cape Verde Ministry of Health, such us avoiding the leaving of waste around, and using repellents or mosquito nets during the night. On the other hand, the Italian students were involved in the development of the emotional and empathetic value of the partnership, both in terms of knowledge and friendship.

Both the Italian and Cape Verde students argued during the class work, when they produced their reports or when they received what had been elaborated by their partner. In these moments, the teachers encouraged more mature reflections, which provided good integration of cognitive and behavioral aspects of learning; i.e. the creation of effective and durable learning.

It was shown that some of the methods used to battle against the diffusion of the mosquito vector might interfere adversely with the primary natural resources (air, 
water, soil). It was also discussed whether it was possible to fight this disease in a sustainable way. Preventive strategies were conditioned by the geomorphology of the territory, and by the complex relationships that connect the geosphere and the biosphere.

In an area consisting mainly of basaltic rock, collecting and burying waste in landfills is not easy [Calvo et al. 2009]. So, waste was often burned outdoors, which produced toxic substances. On the other hand, a massive fight with powerful insecticides might contaminate objects and environments with which people are in contact, and at the same time promote resistance in vectors of the disease.

For this reason, it is important to be aware of the risk of breaking the delicate balances by activating unexpected consequences. The strategies proposed by the Cape Verde students (Figure 2) demonstrated an awareness of these risks, as they were involved in a clear example of a sustainable campaign against dengue fever. The students proposed to collect the waste, clean the roads, and avoid leaving water in containers like bottles or cans, and also in plant vases. In particular, they were aware of the link between waste and disease, because water stagnates in waste, and there the mosquitoes can lay their eggs. Moreover, they knew that cleaning the environment, both in their town and in the countryside, is an effective method to fight against dengue fever. Indeed, mosquitoes can have difficulties in the completion of their life cycle without waste.

We recall, for example, the justifiable pride of the teacher Luisa and her 42 students from Praia (the class that has developed the twinning relationship for 6 consecutive years) to report to their partners how they had been involved in fighting the epidemic, checking around their neighborhood, and urging adults to take the precautions they had learnt at school (the same that were suggested by the Ministry of Health). They felt that they were active citizens in their community; at the same time, they shared this with their Italian friends, aware that they had something to teach their partner.

The roles played by both of the partners linked the knowledge about the natural dynamics of our planet with the development of appropriate behavior, to contribute to the education and training of responsible citizens and to preserve and protect the environment. The project did not really propose original solutions; on the contrary, it mainly focused on the personal awareness of hazard determined by the diffused presence of waste, and of the possibility of acting personally to prevent and to mitigate the diffusion of the outbreak.

\section{Conclusions}

The affective elements involved in the twinning relationship, combined with the surprise and the sense of wonder aroused by the differences that were discovered during the course of the experience, encouraged the development of personal social and cooperative skills. These were to be a powerful stimulus to improve learning and developing the cognitive skills of the students [Cavallini 1995, Alfieri et al. 2000].

From the perspective of the cognitive viewpoint, the comparison was highly successful for the detection of the different characteristics of the two countries (Piedmont, Italy, and Cape Verde). The most obvious difference was due to the geological setting of these two countries: they are very different both in lithology (Cape Verde rock is mostly igneous rock) and morphology (in Cape Verde there are many gorges carved into the rock where waste can accumulate and be transported by the wind and the infrequent but heavy rainfall).

From the perspective of affective and emotional understanding, the comparison revealed rather surprising similarities in the ways in which the students interacted with family, in school practice, and in relation to the educators. They recognized similarities in the wrong habits and disrespectful behavior towards the environment and its balance. They discovered a non-sustainable use of resources (water in particular), and a lack of reuse and recycling of raw materials.

Acknowledgements. This study was supported by the Italian Ministry of Universities and Research (MIUR) as 60\% funds (to EF), and by funds from the Regione Piemonte assigned to the CISAO for the Projects "Reflections and proposals of young people in schools of Piedmont and the Republic of Cape Verde, to raise awareness of the risks and develop best practices in waste management" (2008) and "From the discovery to the awareness of environmental degradation situations. Knowledge of appropriate practices to mitigate the risks involved and selection of appropriate behaviors by school students of Piedmont and Republic of Cape Verde" (2009).

\section{References}

Alfieri, F., M. Arcà and P. Guidoni (2000). I modi di fare scienze: come programmare, gestire, verificare, IRRSAE Piemonte; Bollati Boringhieri, 604 pp.

Calvo, A., S. Capuano, E. Ferrero and G. Mortara (2009). Aspects de la gestion des déchets dans quelques municipalités du Cap Vert, In: Actes du $5^{\mathrm{e}}$ Colloque Interunivers, Turin-Sahel, Bobo-Dioulasso 10-12.04.2009, 187-203.

Cavallini, G. (1995). La formazione dei concetti scientifici. Senso comune, scienza, apprendimento, La Nuova Italia, Firenze, $511 \mathrm{pp}$.

Cattadori, M., F. Florindo and F. Rack (2011). Short- and long-term effects in the school system of a research immersion experience for science educators: An example from ANDRILL (Antarctic Geological Drilling), Geosphere, 22, 1330-1339.

Ebbutt, D. (1985). Educational action research: Some general concerns and specific quibbles, In: Qualitative Methods: Lewes, UK, Falmer Press, 152-174. 
Ferrero, E., A. Cappa, P. Lovesio, R. Prando, E. Molinaro and G. Mortara (2006). Proposte di educazione alla sostenibilità attraverso un progetto di gemellaggio e cooperazione, In: Atti del $3^{\text {rd }}$ World Environmental Education Congress: Torino (Italy) 2-6 Ottobre 2005, 121-125.

Ferrero, E., D. Gimigliano and G. Mortara (2007). Perception des risques géologiques à travers un parcours interculturel. Jumelage entre les écoles du Piemont (Italie) et de la République du Cap Vert, In: Actes $4^{\mathrm{e}}$ Colloque Interunivers. Turin-Sahel. Université Abdou Moumouni de Niamey (Niger), 10-12 gennaio 2007, pp. 282-293.

Ferrero, E., A. Magagna and A.C. Ranzenigo (2009a). Avec la collaboration de E. Bicchi, M. Morando, A. Ruggiero, Coopération internationale: la réalisation d'Expositions Thématiques comme moyen d'éducation au développement durable environnemental, In: Acte du $5^{\mathrm{e}}$ Colloque Interunivers, Turin-Sahel, Bobo-Dioulasso, Burkina-Faso 10-12.04.2009, Résumés des Communications: $10,122-140$.

Ferrero, E., D. Di Rocco, A. Calvo, S. Capuano and G. Mortara (2009b). La perception du concept de déchet en lien avec les dynamiques des systèmes naturels. Un parcours didactique dans l'enseignement obligatoire du Piémont et du Cap Vert, In: Acte du $5^{\mathrm{e}}$ Colloque Interunivers, Turin-Sahel, Bobo-Dioulasso 10-12.04.2009, Resumés des Communications: 11, 141-153.

Fidalgo de Barros, A. (2009). Un Natale senza Dengue, S.O.S. Vinha Maria Chaves a Fogo. Progetto Santa Cruz a Santiago, Uomini per gli uomini, 4.

Hayes, D., D. Symington and M. Martin (1994). Drawing during science activity in the primary school, Intl. J. Sci. Educ., 16, 265-277.

Minutti, L., and A. Vescovi (1998). La formazione delle rappresentazioni mentali e dei concetti. L'importanza delle immagini e dei modelli nella didattica, Naturalmente XI, 4, 43-48.

Viale, M. (2011) Analisi delle concezioni spontanee sul tema dei rifiuti in allievi di scuole del Piemonte e di Capo Verde. Da un'esperienza di gemellaggio alla comparazione e alla sintesi della concezione dei rifiuti in ambiente scolastico, Unpublished Thesis Report, Corso di Laurea in Evoluzione e Diversità nei Sistemi Naturali, Faculty of Sciences M.F.N, Torino University.

${ }^{\star}$ Corresponding author: Michela Viale,

Università di Torino, Dipartimento di Scienze della Terra,

Torino, Italy; email: michelaviale@msn.com.

(C) 2012 by the Istituto Nazionale di Geofisica e Vulcanologia. All

rights reserved. 